\title{
Sustaining Minor Millet Production in Hilly Areas of Uttarakhand through Intercropping of Minor Millets and Pulses- A Review
}

\author{
Shalini $^{1}$, Brijbhooshan ${ }^{2 *}$ and V.K. Didal ${ }^{2}$ \\ ${ }^{1}$ Department of Agronomy, G.B. Pant University of Agriculture \& Technology, \\ Pantnagar-263 145, India \\ ${ }^{2}$ Department of Agronomy, Prof. Jayashankar Telangana State Agricultural University, \\ Hyderabad-500 030, India \\ *Corresponding author
}

Keywords

Minor millets, Pulses, Soil and water conservation, Land equivalent ratio

\section{Article Info}

Accepted:

04 October 2019

Available Online:

10 November 2019
Agriculture in the mountains of Uttarakhand is mostly subsistence farming where small millets occupy an important place in the agriculture of the Uttarakhand especially in hilly regions. Small millets are grown up to an altitude of $3000 \mathrm{~m}$ above sea level in both pure and mixed stands and under Jhuming (shifting) cultivation. In Uttarakhand, 55\% of the total cultivated area is under rainfed cultivation and millets are especially valued for filling specific niches because they often succeed under stressful situation where other crops fail to produce an acceptable harvest. Minor millets and pulses both have a great potential to survive under stress condition as compared to other cereal crops. Intercropping of pulses with minor millet can not only sustain millet production in Uttarakhand but also can conserve soil and water loss along with complementary use of nutrients. Millets based intercropping and sequential cropping of millets with pulse recorded more system yield with less weeds, insects and diseases infestation in the crop. Research findings showed that inclusion of legumes with millets in proper row can achieve higher net return, more crop equivalent yield with less cost of cultivation than sole cropping of finger millet.

\section{Introduction}

Millets have been cultivated for around 3,000 years making them an integral part of the culture and history of India. Millets are not only food grains; they are still intricately interwoven in the socio-cultural fabric of numerous regions. The millets are known to be low in dietary bulk, high in nutrient density and known for its good profile of amino acids. Millets are highly nutritious and has antioxidant properties which provide balanced nutrition (Misra et al., 2014). Uttarakhand is one of the leading state in the production of 
small millets producing 89 thousand tonnes (Indian Agriculture Statistical Report, 2011) primarily finger millet (Eleusine coracana), kodo millet (Paspalum scrobiculatum), little millet (Panicum sumatrense), foxtail millet (Setaria italica), proso millet (Panicum milliaceum) and barnyard millet (Echinochloa frumentacea). Crops and cropping systems in the central Himalayas region are diverse due to large agro-ecological and cultural diversity, which has led to variable cropping patterns.

About $80 \%$ of people in the Garhwal hills of the central Himalayas practice subsistence agriculture (Maikhuri et al., 2001). Intercropping of short growing legumes in wider inter row spaces of millet crops provide sufficient cover on the ground there by reducing erosion by preventing rain drops from hitting the bare soil where they tend to seal surface pores, prevent water from entering the soil and increase surface runoff hazards from the sloping cultivated fields. Millets are grown in low fertile soils. These are the ideal crops for climate crisis because millets are $\mathrm{C}_{4}$ carbon sequestrating crops contributes to the reduction of $\mathrm{CO}_{2}$ in the atmosphere; besides being water efficient so can withstand low soil moisture conditions in rainfed areas.

Deeper and more abundant roots, pulse crops can utilize greater amounts of water stored deep within the soil and can withstand with drought better than shallow-rooted crops. The deep tap root system of pulse crops, make them more suitable for intercropping with shallow-rooted crops, like millets, which are often rainfed. The inclusion of pulses in multiple cropping systems, such as intercropping or simple crop rotation, is important for the sustainable management of soil nutrients, for improving soil structure and overall, it is an important step towards implementing more sustainable agricultural practices.
Intercropping a legume with a non-legume would be more valuable because of the advantage to the non-legumes from nitrogen fixed by the legumes. Velayutham and Somasundaram (2000) recorded that pulses leave $20-25 \mathrm{~kg} / \mathrm{ha}$ of nitrogen in the soil at the time of harvest, which is utilized by the subsequent crop and tremendous leaf fall will form best source of organic matter. Furthermore, two crops differing in height, canopy, adaptation and growth habits grow simultaneously with least competition (Bhatti et al., 2006), greater yield stability over different seasons, better use of land resources, possibility of better control of weeds, pests and diseases (Benites et al., 1993; Jensen, 1996; Chu et al., 2004). Adoption of locationspecific intercropping systems in grey areas of the state is the best alternative to increase the production of millets and pulses. CRIDA (2002) found that intercropping of legumes with finger millet distinctly advantageous over sole cropping. Hence some selective work has been reviewed for different indices of intercropping to see the beneficial effect of millets intercropping with pulses.

\section{Soil and Water Conservation}

Intercropping systems control soil erosion by preventing rain drops from hitting the bare soil where they tend to seal surface pores, prevent water from entering the soil and increase surface runoff (Seran and Brintha, 2010). The studies on cropping system shown that intercropping with specific plant geometry and selection of compatible crop with suitable varieties is profitable practice and to make proper use of available soil moisture and nutrients more efficiently and thus improving productivity of rainfed crops (Kujur et al., 2010). Cropping systems also play a role in reducing soil erosion. For example, in Burkina Faso, a mixed crop of sorghum and cowpea reduced runoff by $20-30 \%$ compared to sorghum alone and by $5-10 \%$ compared to 
cowpea alone, resulting in a reduction in soil erosion of 80 and $45-55 \%$, respectively (Zougmore et al., 1998). Mixed cropping finger millet with black gram reduced runoff by $17.5 \%$ and soil loss $10.6 \mathrm{t} \mathrm{ha}^{-1}$ and with pigeonpea reduced runoff by $18.0 \%$ and soil loss $10.9 \mathrm{t} \mathrm{ha}^{-1}$ (Dass and Sudhishri, 2010). Average data of 3 years of strip cropping of groundnut with finger millet revealed that runoff conservation potential of finger millet + ground nut in the strip ratios of $6: 4,8: 4,10: 4$ and 12:4 was 22.4, 11.9, 10.6 and $8.7 \%$, respectively, compared to sole finger millet (Jakhar et al., 2015). Zougmore et al., (2000) reported that sorghum-cowpea intercropping reduced runoff by 20-30\% compared with sorghum sole crop and by $45-55 \%$ compared with cowpea monoculture. Moreover, soil loss was reduced with intercropping by more than $50 \%$ compared with sorghum and cowpea monocultures.

\section{Growth and Yield}

The yielding ability of a crop is reflected through its yield attributing characters. The yield attributes of little millet like number of productive tillers per hill and test weight was found to be increased when intercropped with pigeon pea at 6:1 ratio (Sharmili and Manoharan, 2018). Yadav (2010) reported that intercropping of finger millet + french bean (3:1) gave significantly highest grain yield (21.61 and 27.30 q/ha during 2007 and 2008, respectively) than the sole crop of finger millet (16.85 and $17.77 \mathrm{q} / \mathrm{ha}$ during 2007 and 2008, respectively). Little millet and pigeon pea intercropped in 6:2 row ratio produced significantly higher dry matter production, ear length, grain weight, grain yield of little millet and pigeon pea as compared to their sole cropping (Kumar et al., 2008). Nigade et al., (2012) found that significantly highest finger millet grain equivalent yield (44.36 q/ha) was observed where black gram was taken as intercrop in finger millet in 8:2 row proportion and the grain equivalent yield was increased in the tune of 42 to 57 per cent over sole cropping. Dass and Sudhishri (2010) reported that improvement in yield attributes of finger millet when intercropped with black gram could be ascribed to the ability of black gram to fix atmospheric $\mathrm{N}$ and supply it to the associated finger millet, better moisture conservation, suppression of weeds and higher sunshine availability to relatively taller plants of finger millet. He also reported that yield of pigeon pea both in sole and inter cropping was 25 and $57 \%$, respectively higher than black gram under similar growing practices, thus, constituting a better choice for intercropping with finger millet. Pradhan et al., (2014) reported that intercropping of finger millet with pigeon pea in 4:1 row ratio recorded significantly higher growth parameters than with sesame, soyabean, horse gram, black gram and niger intercropping in similar row ratio. Raghavulu and Rama Rao (1994) revealed significant increase in yield components when foxtail millet was intercropped with pigeon pea in 5:1 row ratio as compare to $1: 1$ row ratio. Higher grain yield of pigeon pea in all row ratios could be attributed to higher yield attributes, higher population and least competition due to better planting arrangement (Singh et al., 1994).

\section{Land Equivalent Ratio (LER)}

Land equivalent ratio in intercropping indicates the land productivity. The LER is a standardized index that is defined as the relative area required by sole crops to produce the same yield as intercrops (Mead and Willey, 1980). At Ranichauri, Uttrakhand, Singh and Arya (1999) observed that finger millet and soybean mixed cropping system (9:1 seed mixture) recorded higher LER (1.35) as compared to finger millet + rice bean (1.21) and finger millet + rajma mixed cropping system and sole crop of finger millet. Patil (2003) reported that finger millet + pigeon pea 
intercropping at 4:1 ratio recorded the highest land equivalent ratio (1.48) for two years indicating $48 \%$ more land use efficiency over the sole cropping of finger millet. Ramamoorthy et al., (2003) reported that finger millet + determinant type of field bean intercropping recorded higher LER (1.48) as compared to finger millet + field bean (indeterminant type) intercropping system in $8: 2$ row ratio (1.45) and sole crop of finger millet (1.00) at Coimbatore. Padhi et al., (2010) reported that intercropping system of pigeon pea (UPAS -120) + finger millet (Bhairabi) at 2:4 row ratio recorded higher LER (1.42) as compared to pigeon pea (UPAS- 120) + finger millet (PR- 202) in 2:4 row ratio. Manjunath and Salakinkop (2017) also recorded higher LER under 4:2 row ratio of soybean + foxtail millet compared to any of the sole and intercropping of soybean and little millet in 2:1 row ratio. Highest LER (1.34) was recorded from Finger millet + pigeonpea (5:2 and 6:2), which was significantly higher than Finger millet + black gram at all the row ratios except at 5:2 (Dass and Sudhishri, 2010).

\section{Crop equivalent yield}

Crop equivalent yield shows the sum of equivalent yields of main and intercrops. The yields of different intercrops are converted into equivalent yield of anyone crop based on price of the produce. Lal and Ray (1976), proposed economics of crop by converting grain/seed/fodder etc. in terms of gross return for valid comparison and obtained wheat equivalent yield as $\mathrm{Ci}=\mathrm{Pci} / \mathrm{Pw}$ where, $\mathrm{Pci}$ and $\mathrm{Pw}$ are per unit prices of ith crop and wheat, respectively. Patil et al., (2010) recorded that finger millet + pigeonpea and fingermillet + blackgram both in $4: 2$ row ratio produced $77.7 \%$ and $67.4 \%$ higher finger millet equivalent yield, respectively over broadcast sown finger millet (Farmers' practice). Sharmili and Parasuraman (2018) observed that the highest little millet equivalent yield was recorded with 4:2 row ratio of little millet and pulses followed by $2: 1,6: 2$ and 3:1 row ratios. Relay cropping of little millet + horse gram recorded significantly higher little millet equivalent yield than that obtained under little millet alone. Higher little millet equivalent yield was recorded in intercropping of little millet and pigeonpea in 6:2 row ratio with or without horsegram sequence as compared to rest of the treatments (Prasanna Kumar et al., 2008). Dubey and Shrivas (1997) postulated that higher yield in term of kodo millet equivalent yield were obtained by intercropping of kodo millet and pigeonpea in 2:1 planting ratio. Prakash et al., (2005) reported that finger millet was intercropped with wheat and pigeon pea (4:1 and 8:2) which resulted to higher finger millet equivalent yield under intercropping (6.49$6.56 \mathrm{t} / \mathrm{ha}$ ) than under sole cropping (3.37 t/ha). Among different intercropping systems, little millet grown along with small onion and radish recorded higher grain equivalent yield followed by intercropping of little millet with pulses (Sharmili and Manoharan, 2018).

\section{Aggressivity}

This was proposed by Mc-Gilichrist (1960) as an index of dominance. Aggressivity gives a simple measure of how much the relative yield increase in species $\mathrm{A}$ is greater than that for species B in an intercropping system. It is determined according to the following formula: (Intercrop yield of crop A/ Expected yield of crop A)- (Intercrop yield of crop $\mathrm{B} /$ Expected yield of crop B). Zero value of aggressivity indicates that the component crops are equally competitive. The greater the numerical value of Aggressivity, shows greater difference in competitive abilities and hence the larger the difference between actual and expected yield. In case of finger millet + groundnut at 1:1, 2:1, 3:1, 1:2 and 1:3 row ratios showed that the aggressivity values of 
finger millet were positive and for those of groundnut were negative and also observed that aggressivity index was maximum or positive for finger millet when grown in combination with groundnut. Little millet when grown with coriander at 8:2 ratio has recorded the highest aggressivity $(+0.50)$ and the lowest little millet aggressivity of -0.07 was recorded when little millet was grown with blackgram gram at 8:2 ratio.

The aggressivity values for both finger millet + black gram and finger millet + pigeonpea at $3: 2,4: 2,5: 2$ and $6: 2$ row ratios were found negative which indicate that both the pulses have shown dominance over finger millet, however, dominance was the lowest at 6: 2 row ratio (Dass and Sudhishri, 2010). Similar trend was also observed by Ram and Meena (2014).

\section{Competitive ratio}

Competitive ratio (CR) is used to assess competition between different species. It gives a better measure of competitive ability of the crops. The CR represents simply the ratio of individual LERs of the two component crops and takes into account the proportion of the crops in which they are initially sown. Competitive ratio values for finger millet were less than 1 when intercropped with groundnut in the ratio of $(2: 1)$ and $(3: 1)$ proportion and it was lowest with finger millet + Groundnut (3:1); while it was more than one in the ratio of 1:1, 1:2 and 1:3 (Bhagat et al., 2018).

In strip combination of finger millet and groundnut 6:4 row proportion recorded that higher value (1.33) of competitive ratio for finger millet of its intercropping with groundnut which indicated that it was more competitive to groundnut because it had rapid initial growth rate leading to competition for resources with finger millet (Jakhar et al., 2015).

\section{Relative crowding coefficient}

Relative crowding coefficient is a measure of the relative dominance of one species over the other in a mixture. Relative crowding coefficient (RCC) value of all intercropping systems (Coriander, small onion, green gram and black gram) except radish is more than one indicating that all the systems are advantageous and intercropping of little millet with radish is disadvantageous (Sharmili and Manoharan, 2018). Pradhan et al., (2014) also reported negative RCC value (-3.15) in finger millet + niger intercropping combination. The highest RCC value was obtained under intercropping of finger millet + groundnut 1:2 in row proportion with the application of $100 \%$ RDN followed by intercropping of finger millet + groundnut 1:3 row proportion (Bhagat et al., 2018).

\section{Area-time equivalent ratio}

Area time equivalent ratio (ATER) gives more realistic comparison of the yield of intercropping over monocropping in terms of time taken by component crops in the intercrop according to Hiebsch (1978). ATER is calculated by following formula:

ATER $=\{($ LAxDA $)+($ LBxDB $)\} / T$, where LA and $\mathrm{LB}$ are relative yields or partial LERs of the component crops A and B. DA and DB are duration of the crops $\mathrm{A}$ and $\mathrm{B}$ in days and $\mathrm{T}$ is the total duration of the intercropping system in days. Bhagat et al., (2018) reported that finger millet + groundnut 1:2 row proportion recorded higher area-time equivalent ratio as compared to sole groundnut. Area-time equivalent ratios were higher in 4:2 row ratio of soybean + foxtail millet compared to any of the sole and intercropping of soybean and little millet in 2:1 row ratio (Manjunath and Salakinkop, 2017). Among different row ratios of little millet and pigeon pea the higher values of ATER in 6:2 row ratios of little 
millet and pigeonpea - horse gram relay was due to higher yield of component crops in intercropping system due to better utilization of growth resources (Kumar et al., 2009).

\section{Intercropping and nutrient uptake}

Intercropping system gives higher and significant $\mathrm{N}, \mathrm{P}$ and $\mathrm{K}$ uptake in crops as compared to sole cropping system (Kumawat et al., 2012). Tripathi and Kushwaha (2013) reported that nutrient uptake of pearl millet in terms of NPK was significantly increased under intercropping system as compared to sole cropping. Geeta kumari and Shivshankar (1991) studied intercropping of ragi and soybean and observed that available $\mathrm{P}$ status of soil was more in intercropping plot and the uptake of $\mathrm{N}$ and $\mathrm{P}$ was more in pure crop of ragi and soybean due to competition for factors like light, space, moisture etc. in the intercropping system. Oberson et al., (2001) conducted a field experiment at the Carimagua Research Station, Colombia on maize + soybean or maize +cowpea intercropping system and observed that legume based cropping systems maintained higher organic and available $\mathrm{P}$ levels than non legumes in rotation. He also concluded that greater turnover of roots and above ground litter in legume-based intercropping could provide steadier organic inputs and therefore, high $\mathrm{P}$ cycling and availability (Table 1).

Table.1 Some profitable minor millet + pulses intercropping systems for hills

\begin{tabular}{|c|c|c|c|c|}
\hline Crop & System & \multicolumn{3}{|c|}{ Remarks and References } \\
\hline \multirow{8}{*}{ Finger millet } & & $\begin{array}{c}\text { Soil } \\
\text { Loss (t/ha) }\end{array}$ & Run off & \multirow{4}{*}{$\begin{array}{c}\text { Dass and } \\
\text { Sudhishri (2010), } \\
\text { Koraput }\end{array}$} \\
\hline & Finger millet (sole) & 18.6 & 11.10 & \\
\hline & Finger millet +Black gram $(3: 2)$ & 11.7 & 5.2 & \\
\hline & Finger millet + Pigeon pea $(6: 2)$ & 14.0 & 6.6 & \\
\hline & Finger millet + French bean $(3: 1)$ & \multicolumn{3}{|c|}{$\begin{array}{l}\text { French bean is used as a cash crop in the mid } \\
\text { hills of North-West Himalaya (Yadav, 2010), } \\
\text { Uttarakhand }\end{array}$} \\
\hline & Finger millet + Black gram $(3: 4)$ & \multicolumn{3}{|c|}{$\begin{array}{c}\text { Higher system Productivity Index, Higher } \\
\text { LER (1.63). Chandra et al. (2013), Srinagar } \\
\text { (Uttarakhand) }\end{array}$} \\
\hline & Finger millet + Soybean $(1: 1)$ & \multirow{4}{*}{\multicolumn{3}{|c|}{$\begin{array}{l}\text { Profitable millet intercropping systems for } \\
\text { hills with respect to higher net return and soil } \\
\text { health improvement. (Kumar et al., 2008) }\end{array}$}} \\
\hline & Finger millet + Pigeon pea $(8: 2)$ & & & \\
\hline Foxtail millet & Ragi + Soybean /rice bean $(9: 1)$ & & & \\
\hline \multirow[t]{2}{*}{$\begin{array}{c}\text { Barnyard } \\
\text { millet }\end{array}$} & $\begin{array}{c}\text { Barnyard millet }+ \text { Soybean / rice } \\
\text { bean }(9: 1)\end{array}$ & & & \\
\hline & Barnyard Millet-Wheat & & & \\
\hline \multirow[t]{2}{*}{ Kodo millet } & Kodo millet + black gram (4: 1$)$ & & & \\
\hline & Kodo millet+ pigeon pea $(4: 1)$ & & & \\
\hline \multirow[t]{2}{*}{ Little millet } & Little millet + pigeon pea $(6: 1)$ & & & \\
\hline & Little millet + pigeon pea $(6: 2)$ & & & \\
\hline
\end{tabular}




\section{Economics under intercropping system}

In the mid hills of North-West Himalaya, Yadav (2010) observed that finger millet + frenchbean (3:1) intercropping system, gave highest B-C ratio than sole crop. This intercropping not only increase production of finger millet + french bean but also improve the socio-economic condition of the farmers as french bean is used as a cash crop. Prakash et al., (2005) reported that relay cropping of wheat in finger millet (transplanted) + pigeon pea (4:1) registered higher gross return (Rs. 58799/ha), net return (Rs. 23149/ha) and benefit-cost ratio (1.65) as compared to relay cropping of wheat in finger millet (drilled) + pigeon pea (4:1) was found to be the next best in terms of gross return (Rs. 56274/ha), net return (Rs. 20274/ha) and benefit-cost ratio (1.56) at Almora (Uttaranchal). Higher gross and net monetary returns, Rs. 7403 and $3397 /$ ha, respectively were obtain in kodo millet + pigeon pea intercropping and also an additional returns of Rs. $904 \mathrm{ha}^{-1}$ was obtained in intercropping over the sole crop of kodo millet (Dubey and Shrivas, 1997). Sharmili and Manoharan (2018) reported that when little millet intercropped with green gram at 8:2 ratio, recorded higher gross return (Rs. 57,036/ha), net return (Rs. 35,531/ha) and benefit-cost ratio (2.65) and followed by little millet with black gram at 8:2 ratio and this higher return was due to higher price of pulses. Higher net returns (Rs. 23277/ha) and benefit-cost ratio (5.90) were recorded under strip cropping of finger millet + pigeon pea as compared to sole crop of finger millet [Net returns (Rs. 14854/ha) and B-C ratio (4.30)] (Ramamoorthy et al., 2003). Intercropping system of pigeon pea (UPAS-120) + finger millet (Bhairabi) was found to be the most economic followed by pigeon pea (UPAS120) + finger millet (PR 202) with comparable net returns at 2:4 ratio (Padhi et al., 2010). Gross returns, net returns and B-C ratio were significantly higher in 4:2 row ratio of soybean + foxtail millet compared to any of the sole and intercropping of soybean and little millet in 2:1 row ratio (Manjunath and Salakinkop, 2017). Highest net returns (Rs. 9,665/ha) accrued from 6:2 row ratio of finger millet + pigeon pea were thrice higher than broadcast sown sole finger millet and twice higher than mixed sown finger millet + pigeon pea. Benefit: cost (B: C) ratio was also the highest for $6: 2$ row ratio of finger millet + pigeon (1.0) (Dass and Sudhishri, 2010).

Uttarakhand hills are largely dominated by millets diversity contributing a major part in millet production in the country hence, there is a great scope to utilize millet diversity by intercropping with legumes. Intercropping of millets with pulses can reduce the use of external inputs due to the complementary use of nutrient and water resources by the intercrop components. The use of legumes in this system contributes for improving the nutrients status for the millet crops and reduction of the crop loss risk besides increasing overall productivity and income.

Soil erosion, less moisture conservation and declining organic matter are greater cause of concern that can be addressed with creation of soil cover over the land by legumes. Among the intercropping systems, finger millet + pigeon pea (6:2) / finger millet + black gram (3:2) can reduce soil loss and runoff. Finger millet + Frenchbean (3:1) is found a profitable intercropping system in the mid hills of NorthWest Himalaya. Intercropping of soybean / urd bean / pigeon pea/rice bean with finger millet, Little millet, barnyard millet and Kodo millet accounted for higher economic returns than other system of finger millet with field bean / cowpea / green gram.

\section{Certificate}

This is to certify that the article or its data has not been sent/will not be sent elsewhere for publication. 


\section{References}

Benites, J.R., McCollum, R.E. and Naderman, G.C. 1993. Production efficiency of intercrops relative to sequentially planted sole crops in a humid tropical environment. Field Crops Res., 31: 118.

Bhagat, S.B., Nikas, S.B., Dahiphale, A.V., Dhekale, J.S. and Mardane, R.D. 2018. Effect of nitrogen levels and intercropping on yield and economics of finger millet (Eleusine coracana G.). Pharma Innov. J., 7(10): 651-654.

Bhatti, I.H., Ahmad, R., Jabbar, A., Nazir, M.S. and Mahmood, T. 2006. Competitive behavior of component crops in different sesame-legume intercropping systems. Int J Agri Bio., 8(2): 165-167.

Chandra, A., Kandari, L.S., Vikram, S.N., Maikhuri, R.K. and Rao, K.S. 2013. Role of Intercropping on production and land use efficiency in the central Himalaya, India. Environ. We Int. J. Sci. Tech., 8(2): 105-113.

Chu, G.X., Shen, Q.R. and Cao, J.L. 2004. Nitrogen fixation and $\mathrm{N}$ transfer from peanut to rice cultivated in aerobic soil in intercropping system and its effect on soil N-fertility. Plant and Soil, 263: $17-27$.

CRIDA, 2002. Annual Report. Central Research Institute of Dryland Agriculture, Santoshnagar, Hyderabad, Telangana.

Dass, A. and Sudhishri, S. 2010. Intercropping in fingermillet (Eleusine coracana) with pulses for enhanced productivity, resource conservation and soil fertility in uplands of Southern Orissa. Indian J Agron., 55(2): 89-94.

Dubey, O.P. and Shrivas, D.N. 1997. Assessment of productivity and economics of kodo millet (Paspulum scrobiculatum) based inter cropping system under rainfed conditions.

Indian J. Agron., 42(2): 224-227.

Geeta Kumari, V.L. and Shivashankar, K. 1991. Studies on organic amendments and carbon dioxide enrichments in ragi-soybean intercropping. Indian $J$. Agron., 36(2): 202-206.

Hiebsch, C.K. 1978. Camping intercrops with monocultures. In agronomic economic research on soils of the tropics. Ann Report. North Carolina State Univ., Raliegh, N.C. pp187-200.

Jakhar, P., Adhikary, P. P., Naik, B. S. and Madhu, M. (2015). Finger milletgroundnut strip cropping for enhanced productivity and resource conservation in upland of Eastern Ghats of Odisha. Indian J. Agron., 60(3): 365-371.

Jensen, E.S. 1996. Grain yield, symbiotic $\mathrm{N}_{2}$ Fixation and interspecific competition for inorganic $\mathrm{N}$ in pea-barley intercrops. Plant and Soil, 182: 25-38.

Kujur, S., Ahmed, S., Srivastava, G.P. and Singh, C.S. 2010. Performance of pigeonpea (Cajanas cajan) intercropping as influenced by row ratios and duration of finger millet (Eleusine coracana L.). Indian J. Agron., 55(3): 209- 214.

Kumar, B.H.P., Halikatti, S.I. and Ninganur, B.T. 2009. Sustainable intercrop association of pigeonpea (Cajanus cajan) in little millet (Panicum sumatrence L.). Karnataka J. Agric. Sci., 22(4): 887-888.

Kumar, B.H.P., Halikatti, S.I., Hiremath, S.M. and Chittapur, B.M. 2008. Effect of intercropping system and row proportions on the growth and yield of little millet and pigeonpea. Karnataka J. Agric. Sci., 21(4): 479-481.

Kumawat, N., Singh, R.P., Kumar, R., Kumar, A. and Kumar, P. 2012. Response of intercropping and integrated nutrition on production potential and profitability on rainfed pigeonpea. $J$. 
Agric. Sci., 4(7):154-162.

Lal, R.B. and S. Ray (1976). Economics of crop production of different intensities. Indian J. Agric. Sci., 46: 93-96

Maikhuri, R.K., Rao., K.S., Semwal, R.L. 2001. Changing scenario of Himalayan agroecosystems: loss of agrobiodiversity- an indicator of environmental change in Central Himalayas. The Environmentalist. 21: 23-39

Manjunath, M. G. and Salakinkop, 2017. Growth and yield of soybean and millets in intercropping systems. S. $R$. J. Farm Sci., 30(3): 349-353.

Mc- Gilichrist, C.A. 1960. Analysis and competition experiments. Biometrics. 21:975-985.

Mead, R. and R.W. Willey. (1980). The concept of a Land Equivalent Ratio and advantages in yields from intercropping. Exp. Agric., 16: 217228.

Mishra, V., Yadav, N., Pandey, S. and Puranik, V. 2014. Bioactive components and nutritional evaluation of underutilized cereals. Ann Phytomed., 3(2):46-49

Nigade R.D., Karad S.R. and. More S.M.2012. Agronomic manipulations for enhancing productivity of finger millet based on intercropping system. $A d v$. Res. J. crop. 3(1): 8-10.

Obserson, A. Friesen, D.K., Rao, I.M., Buhler, S. and Frossard, E. 2001. Phosphorus transformation in an oxisol under contrasting land- use systems: the role of the soil microbial biomass. Plant and Soil, 237:197-210

Padhi, A.K., Panigrahi, R.K. and Jena, B. K. 2010. Effect of planting geometry and duration of intercrops on performance of pigeonpea- finger millet intercropping system. Indian J. Agric. Res., 44(1): 43-47.

Patil, N.B. 2003. Studies on intercropping of little millet with pigeonpea on alfisols of Dharwad, M.Sc. (Agri.) Thesis, University of Agriculture Science Dharwad, Karnataka, India.

Patil, N.B., Halikatti, S.I., Sajay, Y.H., Kumar, P.B.H., Topagi, S.C. and Pushpa, V. 2010. Influence of intercropping on the growth and yield of little millet and pigeonpea. Int. J. Agric. Sci., 6(2): 573-577

Pradhan, A., Thakur, A., Sao, A. and Patel, D. P. 2014. Biological efficiency of intercropping in finger millet (Eleusine coracana (L.) Gaertn) under rainfed condition. Int. J. Curr. Microbiol. App. Sci., 3(1): 719-723.

Prakash, V., Chandra, S. and Srivastva, A.K. 2005. Relay cropping of wheat (Triticum aestivum) in finger millet (Eleusine coracana) + pigeon pea (Cajanus cajan) intercropping system under rainfed conditions in mid- hills of north-west Himalaya. Indian $J$. Agric. Sci., 75(10): 676-678.

Prasanna Kumar, B.H.S., Halikatti, I., Hiremath, S.M. and Chittapur, B.M. 2008. Effect of intercropping system and row proportions on the growth and yield of little millet and pigeonpea. Karnataka j. Agric. Sci., 21(4): 479481

Raghavulu, P. and Ramarao, K. 1994. Studies on sateria + pigeonpea intercropping systems in scare rainfall zone of Andhra Pradesh. Mysore J. Agric. Sci., 28: 314-318.

Ram, K. and Meena, R.S. 2014. Evaluation of pearl millet and mungbean intercropping systems in arid region of Rajasthan. Bangladesh J. Bot., 43: 367-370.

Ramamoorthy, K. Christopher Laurduras, A., Radhamani, S., Sankaran, N. and Thiyaghorasan, T.M. 2003. Effect of intercropping of field bean on productivity of finger millet under 
rainfed condition. Crop Res., 26(3): 515-518.

Seran, T.H. and Brintha, I. 2010. Review on maize based intercropping. J. Agron., 9(3): 135-145.

Sharmili, K and Parasuraman, P. 2018 Effect of little millet based pulses intercropping in rainfed conditions. Int. J. Chem. Stud., 6(6): 1073-1075

Sharmili, K. and Manoharan, S. 2018. Studies on intercropping in rainfed little millet (Panicum sumatrense). Int. J. Cur. Microbio. App. Sci., 7(2): 323-327.

Singh, R.V. and Arya, M.P.S. 1999. Nitrogen requirement of finger millet + pulse intercropping system. Indian J. Agron., 44(13): 47-50.

Singh, V., Singh, R.P. and Panwar, K.S. 1994. Effect of intercropping systems on light interception, dry matter partitioning and grain yield of pearl millet and pigeonpea. Crop Res., 7 (2): 184-189.

Tripathi, A.K. and Kushwaha, H.S. 2013. The appropriate $\mathrm{N}, \mathrm{P}$ and $\mathrm{K}$ dose for greater productivity of pearl millet intercropping with pigeonpea under rainfed environment of Bundelkhand region. Annual Agric. Res. New series, 24(1):36-43.
Velayutham. A. and Somasundaram, E. 2000. Change of management for pulses intercropping system. Proceedings of training on recent advances in pulse crop production technology held at Centre for advanced studies in agronomy, Tamil nadu Agricultural University, Coimbatore from September 13, 2000 to October 30, 2000, p. 141.

Yadav, R. 2010. Production potential of finger millet and French bean intercropping under rainfed conditions of Uttarakhand. J. Food Legumes, 23(2): 121-123.

Zougmore, R., Kambou, F. N., Ouattara, K. and Guillobez, S. 2000. Sorghumcowpea intercropping: An effective technique against runoff and soil erosion in the Sahel (Saria, Burkina Faso). Arid Land Res. Manag. 14: 329342.

Zougmore, R.F., Kamboun, K., Ouattara, S. and Guillobez, S. 1998. The cropping system of sorghum-cowpea in the prevention of runoff and erosion in the Sahel of Burkina. International Development Research Centre, Ottawa, pp. 217-224.

\section{How to cite this article:}

Shalini, Brijbhooshan and Didal, V.K. 2019. Sustaining Minor Millet Production in Hilly Areas of Uttarakhand through Intercropping of Minor Millets and Pulses- A Review. Int.J.Curr.Microbiol.App.Sci. 8(11): 397-406. doi: https://doi.org/10.20546/ijcmas.2019.811.050 